\title{
PROACTIVE STRATEGY FOR THE PREVENTION OF SOCIAL PROBLEMS
}

УДК 316.43:304.2

DOI https://doi.org/10.32843/2663-

5208.2020.16.3

\section{Біскуп В.С.}

к.соціол.н., доцент кафедри психології

та соціальної роботи

Тернопільський національний

економічний університет

\section{Надвинична Т.Л.}

к.психол.н., доцент кафедри психології та соціальної роботи

Тернопільський національний економічний університет
Випереджальні стратегії управління соціальними системами різної складності визначають успішність їх розвитку. у статті наведено термінологічне та змістове наповнення проактивних і реактивних стратегій як певних типів відповідей на виклики зовнішнього середовища. Установлено, що сутнісними ознаками проактивної спрямованості є орієнтація на випередження можливих загроз, які потенційно очікують на суб'єктів соціального життя. Натомість реактивна стратегія демонструє практику подолання небажаних ситуацій, які вже актуалізовані в теперішньому часі. Продемонстровано переваги проактивних стратегій запобігання можливим соціальним деструкціям із застосуванням теоретичних положень конструктивістського підходу до розуміння френомена соціальних проблем. Визначено, що об'єктивація соціальної проблеми проходить низку етапів, на кожному з яких агенти соціального життя визначають, чи вважати ті чи інші соціальні умови вартими посиленої уваги, усвідомлювати їх як деструктивні або ж незначущі, другорядні. Проактивний підхід до запобігання соціальним проблемам зорієнтований на ідентифрікацію слабких сигналів, які мають лише обриси некерованості, розладу, але випадають із поля зору громадськості, наукової спільноти й не актуалізуються як можлива загроза для майбутнього розвитку соціуму. Запропонована модель проактивної стратегії запобігання соціальним проблемам містить чотири логічно взаємопов'язані етапи, на кожному з яких відбувається випереджальна робота з потенційними суспільними загрозами. Так, проактивний моніторинг спрямовано на розпізнавання нечітких імпульсів, які можуть стати пусковими механізмами для розгортання складних соціальних протиріч; проактивне конструювання пов'язане з розробленням сценаріїв бажаної траєкторії суспільного розвитку; проактивні дії націлені на практичну реалізацію програмних заходів, які покликані запобігти загрозі, а проактивна ресрлексія має на меті критичну оцінку застосованих стратегічних процедур і їх результативність.
Ключові слова: проактивне управління, превенція, конструктивізм, моніторинг, ресрлексія.

Advanced strategies for managing of varying complexity social systems determine the success of their development. The article presents the terminological and meaningful basis of proactive and reactive strategies, as certain types of responses to environmental challenges. It is established that the essential signs of proactive orientation are the focus on anticipating of possible threats that wait of potentially the subjects of social life. Instead, the reactive strategy demonstrates the practice of undesirable situations overcoming that are already relevant today. The advantages of proactive strategies to prevent possible social destruction, with the using of theoretical provisions of the constructivist approach to understand the phenomenon of social problems, are demonstrated. It is determined that the objectification of a social problem passes through a number of stages, due to which the agents of social life determine whether the certain social conditions are worthy of the increased attention, and whether to perceive them as destructive or insignificant, secondary. Proactive approach for the prevention of social problems is focused on the identifying of weak signals that have the outlines of uncontrollability, disorder, fall out of sight of the public, the scientific community and aren't actualized as a possible threat for the development of future society. The proposed model of the proactive strategy for the preventing of social problems contains four logically interrelated stages, each of which consists of a precautionary work with potential social threats. Thus, the proactive monitoring is aimed at the recognizing of fuzzy impulses that can become triggers for the development of complex social contradictions; the proactive design involves the development of scenarios for the desired trajectory of social development; the proactive actions are aimed at the practical implementation of program activities for the threats preventing: and the proactive reflection aims to critically assess the applied strategic procedures and their effectiveness.

Key words: proactive management, prevention, constructivism, monitoring, reflection.
Постановка проблеми. Сучасний світ пронизаний численними протиріччями та незбагненими траєкторіями розвитку. Як окремі особистості, так і транснаціональні корпорації й економіки передових держав звертаються до питань стабілізації та уникнення тих загроз, які можуть їх очікувати в найближчій чи віддаленій перспективі. Прагнення до стабільності $€$ визначальною рисою будь-якого живого організму. Принцип гомеостазу поширюється 
на системи широкого спектру. Динамічні процеси суспільного розвитку є водночас передумовою й наслідком ланцюгових реакцій, які викликають хвилю руйнувань, падіння слабких суб'єктів соціального життя, зародження чи посилення більш адаптованих структур до нових викликів суспільного розвитку. Стиль сучасного світу зорієнтований не стільки на відтворення, скільки на випередження можливих конкурентних переваг своїх суперників. Науковий підхід до зазначеної проблематики значно розширює спектр пояснювальних моделей, водночас намагаючись обґрунтувати їх і в практичному вимірі поєднати з можливістю реалізації в практичній діяльності фахівців різних галузей діяльності. Охоплення широкого спектра випереджальних технологій актуалізує питання концептуалізації знань щодо запобігання негативним тенденціям у соціальній реальності. Активному обговоренню нині підлягає проактивна модель розвитку як окремого індивіда, так і глобальних соціальних систем.

Аналіз останніх досліджень і публікацій. Проактивність як теоретичний конструкт і мета практико зорієнтованих процедур посилення особистісного та суспільного потенціалу перебуває в центрі уваги багатьох як зарубіжних (І. Ансофа, П. Друкера, С. Кові, Ф. Котлера, Д. Майерса, Дж. Роттера, Д. Скотта, В. Франкла та ін.), так і вітчизняних (Т. Андрєєва, Е. Бажина, В. Бодрова, О. Гребешкова, Н. Гуржій, Е. Голінкіної, Н. Коломінського, В. Семиченка та ін.) науковців. Залежно від галузі знань термін «проактивність» постає в специфічному трактуванні зі збереженням власного змістового наповнення - контроль над ситуацією, запобігання, передбачення наслідків різного вектору розвитку, самодетермінація, мотивація, стратегія, динамізм тощо. При цьому розширюються його класифікації, розробляються організаційні механізми проактивних стратегій, але в більшості випадків поза увагою залишаться питання, пов'язані з проактивним управлінням суспільними процесами, технологіями запобігання соціальним проблемам.

Постановка завдання. Теоретична концептуалізація проактивного управління суспільними процесами та розроблення стратегій запобігання негативним явищам у суспільному житті на засадах теорії конструювання соціальних проблем.

Виклад основного матеріалу дослідження. Звертаючись до визначення поняття «проактивність», Стівен Кові, консультант з організаційного управління, справедливо зауважує, що, хоча цей термін досить широко використовується в літературі, присвяченій мистецтву управління, його досить важко відшукати в більшості відомих словників [1, с. 75]. Загалом автор відомого бестселера визначає цей термін як здатність людини нести відпо- відальність за власне життя. Наша поведінка, наголошує С. Кові, є продуктом власного усвідомленого вибору, який базується на цінностях, а не продукт навколишніх умов, заснований на почуттях. Натомість реактивні люди залежать від соціального середовища або, як метафорично зазначає автор, від «соціальної погоди» [1, с. 76]. Отже, проактивність у трактуванні С. Кові пов'язана із суб'єктністю особистості, яка здатна усвідомлено управляти своїм теперішнім і майбутнім. Реактивність заснована на «парадигмі детермінізму», залежності від зовнішнього середовища й обставинах, на які воно не в змозі впливати.

Дослідженню питань проактивності як одній зі стратегій людського життя присвятив праці американський психолог Г. Олпорт, котрий був переконаний, що людині часто приписують таку тактику поведінки, яка базується на повторюваності, пасивності, керованості. Проаналізувавши тогочасну психологічну літературу, Г. Олпорт дійшов висновку, що слова «реакція» й «реактивний» зустрічаються сотні разів, а поняття «проакція» і «проактивний» - тільки один раз [2, с. 65]. Відтак науковець робить важливе зауваження щодо того, що вербальні, а отже, концептуальні інструменти для створення науки про зміни, зростання, майбутнє й можливості поступаються технічному лексикону, який прив'язує дослідника до науки про реакції та регресії.

Проактивна поведінка, за визначенням інших психологів, - це поведінка, яка насамперед намагається змінити середовище, а проактивна особистість виходить за межі ситуаційних обмежень, продукує нові ідеї, змінює місію своїх організацій, знаходить проблеми та вирішує їх. Натомість люди з протилежними якостями не в змозі визначити й використати можливості для змін, демонструють пасивність і терпляче пристосовуються до наявних умов [3, с. 104-105].

Зростаюча конкуренція на внутрішньо-національних і глобальних ринках, потреба у випереджаючих стратегіях збереження та поширення сфер впливу у фінансових і бізнесових інтересах зумовили посилення інтересу науковців і представників топ-менеджменту компаній до переосмислення їхніх форм діяльності. Зокрема, І. Ансофф, засновник і визнаний теоретик зі стратегічного менеджменту, проаналізував різноманітні моделі управління компаній та організацій і дійшов висновку, що реактивний стиль управляння полягає в прагненні керівництва мінімізувати стратегічні зміни, уникненні перегляду товарних і ринкових позицій. Така позиція компанії є відносно успішною за умови стабільності ринку. Натомість менеджери з проактивною установкою здатні розпізнавати необхідність змін ще до того, як розгорнеться криза [4, с. 415-418], 
а відтак є більш захищеними в умовах постійних трансформаційних змін. Так, Д. Аакер, фахівець у галузі бренд-менеджменту, наполягає, що метою стратегії $€$ не пасивне реагування на події, які відбуваються в зовнішньому середовищі, а активний вплив на них, бажано випереджальний. Отже, стратегія розвитку будь-якої соціальної структури повинна бути проактивною з двох причин: щоб зберігати впевненість у тому, що існує можливість відстежувати найважливіші зміни в зовнішньому середовищі й швидко реагувати та впливати на них, оскільки зміни в ринковому оточенні можуть мати серйозні наслідки [5, с. 36].

Вітчизняні науковці також не залишаються осторонь від розроблення довгострокових стратегій розвитку. Так, український психолог В. Барко вважає, що проактивний підхід, на відміну від традиційного реактивного управління, базується на ідеї завчасного запобігання проблемам і негараздам як усередині організації, так і в зовнішньому середовищі [6, с. 52]. 3 ним погоджуються й інші дослідники цієї проблеми [7, с. 8] і пропонують, з огляду на актуальні загрози сьогодення, негайно запровадити комплекс проактивних заходів із забезпечення системи економічної безпеки держави загалом, її регіонів і суб'єктів господарювання. Наголошується на функціях «проактивної держави», яка розробляє концепцію модернізації, систему практичних заходів, їх інституційний супровід, а також правила та норми, що формують соціальну довіру і згуртованість суспільства [8, с. 301].

Науковці наголошують, що головними сегментами, які нагально потребують проактивного планування, є зовнішня та міжнародна політика, ідеологічні питання, економічна сфера, інфраструктура, внутрішньополітичні процеси, інформаційна сфера, протидія прямій воєнній агресії тощо. Щоправда, на нашу думку, досі поза увагою залишаються важливі деталі проактивного управління й термінологічні та операційні процедури з'ясування його ключових елементів.

Зважаючи на актуальність визначеної проблематики, до осмислення феномену проактивного управління долучаються науковці, котрі дають таке його емпіричне тлумачення: це запобіжна дія влади, спрямована на досягнення поставлених цілей шляхом завчасного виявлення явних або слабких сигналів про зовнішні збурення, прогнозування потенційних (можливих) сценаріїв розвитку ситуації й реалізації превентивних дій, що орієнтують об'єкт управління так, що всі процеси, які протікають у ньому, будуть спрямовуватися владою, а небажані (можливі) сценарії розвитку подій не будуть реалізовані [9, с. 46]. Погоджуючись із думкою, що проактивне управління це насамперед діяльність із запобігання мож- ливим соціальним негараздам та уникнення можливих соціальних негараздів, додамо, що поняття «влада» в цьому визначенні дещо суперечливе. Отже, уважаємо за необхідне уточнити, що владу тут варто розглядати як один із елементів у структурі управління соціальними процесами, який використовується з метою уникнення узурпації прийняття рішень лише на користь політичних еліт.

Зауважимо, що нині людству доводиться накопичувати досвід проактивних стратегій через значні соціальні кризи, які все частіше супроводжують нашу життєдіяльність і нерідко призводять до значних людських і матеріальних утрат (природні й техногенні катастрофи, епідемії, соціальні та фінансові кризи тощо). у більшості випадків уряди використовують реактивну тактику подолання посталих загроз, які долають лише наслідки й жодним чином не убезпечують наше майбутнє. Але критичний аналіз минулого показує, що лише використання інноваційних методів соціального проектування може забезпечити досягнення бажаного розвитку подій.

Отже, уважаємо, що необхідність більш детального осмислення стратегій проактивного управління соціальними процесами та змінами спричинена щонайменше двома обставинами: стрімким поширенням ідейних, технологічних, наукових інновацій, які змінюють соціальні взаємодії, і виникненням соціальних проблем, а також потенційними ризиками, з якими все частіше зіштовхується людство в розвитку, а звичні реактивні стратегії не завжди дають бажаний результат. 3 метою оптимізації управління соціальними змінами й процесами нами запропонована модель проактиваної стратегії, кожен із етапів якої включає логічно вибудувану послідовність цілеспрямованого впливу на уникнення, запобігання, превенцію розгортання небажаних соціальних проявів (рис. 1).

Далі більш детально розглянемо кожен із етапів пропонованої моделі, особливу увагу акцентуючи на проактивному моніторингу як ключового сегменту, у межах якого відбувається ідентифікація та актуалізація соціальних проблем, що безпосередньо є об'єктами проактивного управління суспільними змінами й процесами.

Отже, проактивний моніторинг. Традиційний (реактивний) підхід щодо дослідження й аналізу соціальних проблем передбачає, що соціальна проблема, яка апріорі має негативне забарвлення та є «шкідливою», існує як об'єктивна умова в структурі суспільства, котру необхідно якнайшвидше виявити, вивчити її природу, установити причину, розкласти на частини й запропонувати оптимальні шляхи вирішення [10, с. 150]. Але все більше науковців схиляються до думки, що такий погляд нині $€$ неефективним і застарілим. 


\section{Проактивний моніториг}

- доаналітичний аналіз та оцінювання проблемних ситуацій 3 орієнтацією на слабкі, неочевидні сигнали соціальної системи, за яких потенційна загроза вже «назріває», але ще не потрапила в поле зору науковців;

- визначення меж «стратегічної зони», що окреслює «територію», на яку потрібно спрямувати проактивний вплив із управління залученням експертного потенціалу, проведення кількісних і якісних соціальних досліджень тощо;

- установлення закономірностей та основних тенденцій зафіксованих подій у соціальному середовищі;

- здійснення комплексного аналізу виявлених змін i встановлення «соціального діагнозу».

\begin{tabular}{|c|}
\hline $\begin{array}{l}\text { Проактивне конструювання } \\
\text { - проектування та вибір найкращої лінії чи сценарію } \\
\text { майбутнього розвитку соціальної системи; } \\
\text { - створення програми дій } 3 \text { урахуванням аналізованих змін, } \\
\text { перспективо спрямованих на уникнення розгортання } \\
\text { деструкцій у функціонуванні суспільних інститутів. }\end{array}$ \\
\hline \\
\hline $\begin{array}{l}\text { Проактивні дії } \\
\text { - прийняття відповідних управлінських рішень, вплив на } \\
\text { фізичне середовище чи поведінку (психологію) людей з метою } \\
\text { запобігання небажаним подіям, явищам, антисоціальним рухам } \\
\text { i заворушенням, деескалація деструктивних суспільних } \\
\text { процесів тощо. }\end{array}$ \\
\hline
\end{tabular}

\begin{tabular}{|c|} 
Проактивна рефлексія \\
\hline \multicolumn{3}{|c|}{ - критична оцінка наслідків обраної стратегії, оперативне } \\
реагування на поточні виклики шляхом переконструювання \\
управлінських рішень; \\
- експертиза отриманих результатів 3 метою співставлення \\
очікуваних наслідків з актуальним станом соціальної системи.
\end{tabular}

\section{Рис. 1. Модель проактивної стратегії} запобігання соціальним проблемам

Так, відомий соціолог Г. Блумер виокремлює цілу низку недоліків, які притаманні цьому підходу, а саме:

- соціологи можуть установити соціальну проблему й відреагувати на неї тільки після того, як вона стала суспільно очевидною та актуальною. Отже, більшість недостатньо виражених, але все жтаки потенційно загрозливих подій чи явищ не потрапляе в поле зору науковців вчасно, а тому може довгий час перебувати в латентному стані й у майбутньому ставати причиною серйозних соціальних трансформацій чи потрясінь, до подолання наслідків яких потрібно залу- чати значну кількість матеріальних і людських ресурсів;

- більшість науковців намагається дослідити об'єктивні умови виникнення тієї чи іншої соціальної проблеми, але, як виявляється пізніше, вони не завжди сприймаються суспільством, а відтак $€$ неважливими для його членів. Тому, на думку Г. Блумера, важливіше досліджувати саме процес, за допомогою якого суспільство визначає, що для нього $€$ проблемою, а що ні, і формує відповідне суб'єктивне ставлення;

- пропоновані варіанти вирішення соціальних проблем, які базуються лише на об'єк- 
тивних наукових фактах і залишають поза увагою реальний процес суспільного реагування на них, є малоефективними [10, с. 151-153].

3 огляду на вищеозначене, інноваційний (проактивний) підхід до визначення соціальних проблем і попередження соціальним проблемам, на нашу думку, має включати т.з. доаналітичний етап, який передбачає орієнтацію, націленість на загрозливі події, які ще не трапилися, але володіють гіпотетичними обрисами ризиків, які, вірогідно, відбудуться, якщо станеться низка інших подій, котрі запустять ланцюг незворотних причинно-наслідкових реакцій. Тобто це ще не проблема, а лише проблемна ситуація, яка може спровокувати її виникнення й розвиток за умови невчасного реагування.

Щоправда, тут $€$ декілька застережень, що випливають із теоретичних напрацювань науковців, які працюють із методологією конструювання соціальних проблем. Щоб діяти на запобігання, завжди необхідно чітко розуміти, що може стати соціальною проблемою, у який спосіб певні соціальні умови набувають цього статусу. Важливо також у процесі проактивного моделювання вирізняти проблему від її передумов і наслідків. Визначення серцевини проблеми та її супутніх складників (історичні контексти, культурні стереотипи, природне чи штучно сконструйоване підґрунтя розгортання, закономірності виникнення й розвитку тощо), а також установлення та чітке окреслення «стратегічної зони» [11, с. 212], на яку потрібно спрямувати проактивний вплив, $\epsilon$ ключовим напрямом проактивного реагування на запобігання їй.

Завершальним моментом цього етапу $€$ постановка «соціального діагнозу», який дає змогу на основі ґрунтовного та системного аналізу всіх загрозливих сигналів, що надходять із соціальної системи, скласти «загальну картину проблеми» та перейти до наступного етапу - проактивного конструювання. Основне його завдання - на основі попередніх даних прорахувати всі можливі варіанти розвитку подій та обрати найбільш оптимальні з них. Найефективнішими інструментами, які дадуть змогу втілити такі наміри, є науковий проект, основною характеристикою якого є його множинність і варіабельність, тобто можливість обирати найраціональніший шлях руху до зазначеної мети та програму, яка передбачає конкретні кроки втілення задуму [12].

Проактивні дії - прийняття й реалізація конкретних управлінських рішень, що передбачають дотримання чітких кроків реалізації наміченої програми; використання необхідних ресурсів для досягнення максимального результату; забезпечення скоординованого керівництва на всіх рінях управління з метою досягнення поставлених цілей; поточна корекція вже розроблених планів і програм з урахуванням мінімізації ризиків їх упровадження тощо.

Одним із найбільш складних етапів пропонованої моделі проактивної стратегії запобігання соціальним проблемам, на нашу думку, є проактивна рефлексія. Соціальні процеси та явища, перебіг яких є вкрай непередбачуваним і сповненим різноманітними неочікуваними поворотами, надзвичайно складні за своєю природою. Незважаючи на те що всі вони мають закономірності свого функціонування й розвитку, володіють визначеними взаємозв'язками та будовою тощо, усе ж таки існує надзвичайно багато об'єктивних і суб'єктивних чинників, які впливають на перебіг їх виникнення. Науковцям надзвичайно важко віднайти той єдиний правильний шлях, який би забезпечив отримання однозначно позитивного результату в пошуку ефективної проактивної стратегії реагування. Тому, на наш погляд, критичне переосмислення й переоцінка на перший погляд вдалого варіанта вирішення проблеми та своєчасна корекція або й кардинальна його зміна можуть забезпечити отримання максимального результату, адже лише постійний аналіз ситуації та запланованих дій дає можливість вчасно реагувати на виклики і приймати ефективні управлінські рішення.

Висновки 3 проведеного дослідження. Ґрунтовний аналіз наукових джерел і прискіпливий погляд на повсякденну реальність засвідчив, що більшість проблем майбутнього є наслідком недосконалого або часткового вирішення актуальної деструкції в поточній перспективі. Сучасне суспільство звикло реагувати на події, які вже відбулися й реально загрожують його життєдіяльності чи безпеці. У світлі подій останніх десятиліть стає зрозуміло, що така позиція вже давно неефективна та помилкова й загрожує значними економічними, суспільними та людськими втратами. Проактивна стратегія спрямована насамперед на виявлення сигналів, які ще $\epsilon$ «сліпими» для поточної ситуації, тригерів, що є вибуховими за своїми наслідками в майбутньому. Вчасне реагування на них значно збільшує шанси на повне чи часткове уникнення масштабних соціальних криз і катастроф або хоча б дає час на підготовку до них. Отже, використання в зазначеному контексті давно відомих і напрацьованих у науці термінів - моніторинг, конструювання, рефлексія тощо в теорії проактивного управління набуває нового теоретичного та практичного забарвлення. 


\section{ЛIТЕРАТУРА:}

1. Кови Стивен Р. Семь навыков высокоэффрективных людей: Мощные инструменты развития личности / пер. с англ. 4-е изд. Москва : Альпина Бизнес Букс, 2009.

2. Олпорт Г. Становление личности: Избранные труды / под ред. Д.А. Леонтьева. Москва : Смысл, 2002. $462 \mathrm{c}$.

3. Bateman T.S., Crant J.M. The proactive component of organizational behavior: A measure and correlates. Journal of Organizational Behavior. 1993. Vol. 14 (2). P. 103-118.

4. Ансоффф И. Новая корпоративная стратегия. Санкт-Петербург : Питер Ком, 1999. 416 с.

5. Аакер Д. Бизнес-стратегия. От изучения рыночной среды до выработки беспроигрышных решений. Москва : Эксмо, 2007. 464 с.

6. Барко В. Сучасні психологічні аспекти управління персоналом в органах внутрішніх справ. Вісник Академії управління МВС. 2007. № 4. С. 41-52.

7. Помаза-Пономаренко А.Л. Соціальний розвиток і безпека регіонів: державно управлінські аспекти : монограсрія. Харків, 2017. 270 с.

8. Антикризове управління національною економікою : монографрія / І. Малий, І. Радіонова, Л. Єме- льяненко та ін. ; за заг. ред. І. Малого. Київ : КНЕУ, 2017. 368 c.

9. Горбулін В.П. Хроніки передбачень: 2006-2017. Харків : Фоліо, 2017. 255 с.

10. Клаус Н.Г., Свечкарев В.П., Васьков М.А. Проактивное управление в социологии: предметное поле и терминологическая специфика. Научная мысль Кавказа. 2015. № 2 (82). С. 42-48.

11. Блумер Г. Социальные проблемы как коллективное поведение / пер. И. Ясавеева. Контексты современности-II: Актуальные проблемы общества и культуры в западной социальной теории : хрестоматия / сост. и общ. ред. С.А. Ерофреева. 2-е изд., доп. и перераб. Казань : Изд-во Каз. ун-та, 2001. C. $150-159$.

12. Гуржій Н.М., Косяк В.В. Механізм проактивного управління стратегічною маркетинговою стійкістю. Вісник Одеського національного університету. Серія «Економіка». 2013. Т. 18. Вип. 2. С. 57-66.

13. Надвинична Т.Л. Проблемність у контексті психологічного проектування навчальних задач. Проблеми загальної та педагогічної психоло2ії : збірник наукових праць Інституту психології ім. Г.С. Костюка АПН України. Київ, 2008. Т. 10. Ч. 5. C. $400-408$. 